
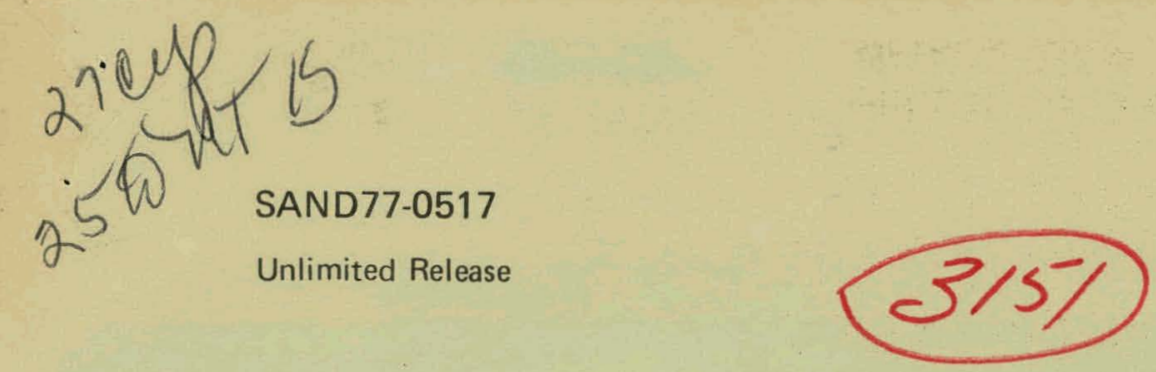

\title{
The Environmental Data Processor of the Adaptive Intrusion Data System
}

Michael S. Rogers

Prepared by Sandia Laboratories, Albuquerque, New Mexico 87115

and Livermore, California 94550 for the United States Energy Research '

and Development Administration under Contract AT (29-1)-789

Printed June 1977 


\section{DISCLAIMER}

This report was prepared as an account of work sponsored by an agency of the United States Government. Neither the United States Government nor any agency Thereof, nor any of their employees, makes any warranty, express or implied, or assumes any legal liability or responsibility for the accuracy, completeness, or usefulness of any information, apparatus, product, or process disclosed, or represents that its use would not infringe privately owned rights. Reference herein to any specific commercial product, process, or service by trade name, trademark, manufacturer, or otherwise does not necessarily constitute or imply its endorsement, recommendation, or favoring by the United States Government or any agency thereof. The views and opinions of authors expressed herein do not necessarily state or reflect those of the United States Government or any agency thereof. 


\section{DISCLAIMER}

Portions of this document may be illegible in electronic image products. Images are produced from the best available original document. 
Issued by Sandia Laboratories, operated for the United States Energy Research \& Development Administration by Sandia Corporation.

\section{NOTICE}

This report was prepared as an account of work sponsored by the United States Government. Neither the United States nor the United States Energy Research \& Development Administration, nor any of their employees, nor any of their contractors, subcontractors, or their employees, makes any warranty, express or implied, or assumes any legal liability or responsibility for the accuracy, completeness or usefulness of any information, apparatus, product or process disclosed, or represents that its use would not infringe privately owned rights.

\section{Printed in the United States of America}

\section{Available from}

National Technical Information Service

U. S. Department of Commerce

5285 Port Royal Road

Springfield, VA 22161

Price: Printed Copy $\$ 3.50$; Microfiche $\$ 3.00$ 


\section{PAGES 1 to 2 WERE INTENTIONALLY LEFT BLANK}




\section{SAND77-0517}

Unlimited Release

Printed June 1977

THE ENVIRONMENTAL DATA PROCESSOR OF THE ADAPTIVE INTRUSION DATA SYSTEM

Michael S. Rogers

TM Development Division 9421

Sandia Laboratories

Albuquerque, NM 87115

\section{ABSTRACT}

A data acquisition system oriented specifically toward snllertinn and processing of various meteorological and environmental parameters has been designed around a National Semiconductor IMP-1.6 microprocessor. This system, called the Environmental Data Processor (EDP), was developed specifically for use with the Adaptive Intrusion Data System (AIDS) in a perimeter intrusion alarm evaluation, although its design is sufficiently general to permit use elsewhere. This report describes in general detail the design of the EDP and its interaction with other AIDS components.

NoTICE This report was prepated as an account or work the United States nor the United States Energy Research and Development Administration, nor any of their employoes, not any of their contractors. subcontracton, of their employees. Makes any whrenty, express or impled,

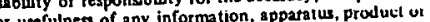
or usefulness of any ir represents that its use would not infringe privately owned rights. 


\section{CONTENTS}

Page

Introduction

Network Description

7

Environmental Data Processor Description

Packaging

APPENDLX 
THE ENVIRONMENTAL DATA PROCESSOR OF THE

- ADAPTIVE INTRUSION DATA SYSTEM

Introduction

The advent of the microprocessor has made practical many concepts heretofore deemed unfeasible because of the economic and/or engineering investment required for a suitable implementation. One such application is to small, moderately powerful, dedicated acquisition systems for which minicomputers represent overkill and for which random logic is too complex and unwieldy.

The microprocessor-bașed syștem to he described was developed specifically for a perimeter intrusion alarm evaluation conducted by Sandia at Rocky Flats, Colorado, and at the Sandia Alarm Development Laboratory (SADL): in Area III, Building 6600, Sandia Laboratories, Albuquerque, New Mexico. However, its design is sufficiently general to permit utilization in other applications.

The system was designed around a National Semiconductor IMP-16 microprocessor for several reasons. At the time of initial system definition, the IMP-16 was one of the few proven microprocessors on the market. Also, the IMP's instruction repertoire.includes

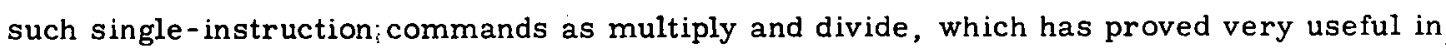
implementing some of the mathematical algorithms required for processing much of the data. Also, the 16-bit word size in the IMP was attractive because most other system components utilized a 16-bit word structure, and all interconnecting data buses were 16-line. The IMP-16 has proved to be a powerful system tool in this application and has functioned reliably. However, some of the newer generation microprocessors may possibly be better choices in that they require much less overhead logic and have whole families of specialized support circuits that greatly simplify both hardware and software. Nonetheless, the IMP-based unit has demonstrated the feasibility of microprocessor-based acquisition systems. Flexibility, adaptability, computational power, and susceptibility to miniaturization are all characteristics of a microprocessor-based system which give it a distinct and commanding advantage over random logic systems.

\section{Network Description}

The overall network of which the Environmental Data Processor (EDP) is a part is shown in Figure 1. This network is known as the Adaptive Intrusion Data System (AIDS), 
and most of the functional blocks shown in Figure 1 are described in other Sandia reports. Table I lists the meteorological parameters currently being collected by the EDP at Rocky Flats, Colorado. As shown in Figure 1, most of the various sensors are located on a 10-foot tower, except for the potential gradient sensor, which is placed on the ground, and the tipping-bucket rain gage, which is located on the roof of the instrumentation trailer. Also, at Rocky Flats, the two remote wind speed and wind direction sensors are mounted on two additional towers on which cameras are also mounted. All of the environmental sensors and sensor processors are off-the-shelf commercial units.

The raw sensor outputs are converted to easily digitized analog levels by the sensor processors. The sensor processors also provide régulated power to the sensors when such power is necessary for operation. The analog outputs of the sensor processors in turn feed the EDP, where cach is sampled 10 times per second, digitized, scalcd, and further processed as appropriate to the particular data parameter. The EDP converts all input data to proper engineering units and formats the data for display and subsequent storage on magnetic tape. The processed metro data are transferred from the EDP's memory on command to the Memory Controlled Processor (MCP), which interposes the environmental channels with other data. The composite data stream is then directed into a mass memory where, depending upon various criteria, it is either discarded or transferred to magnetic tape for permanent storage.

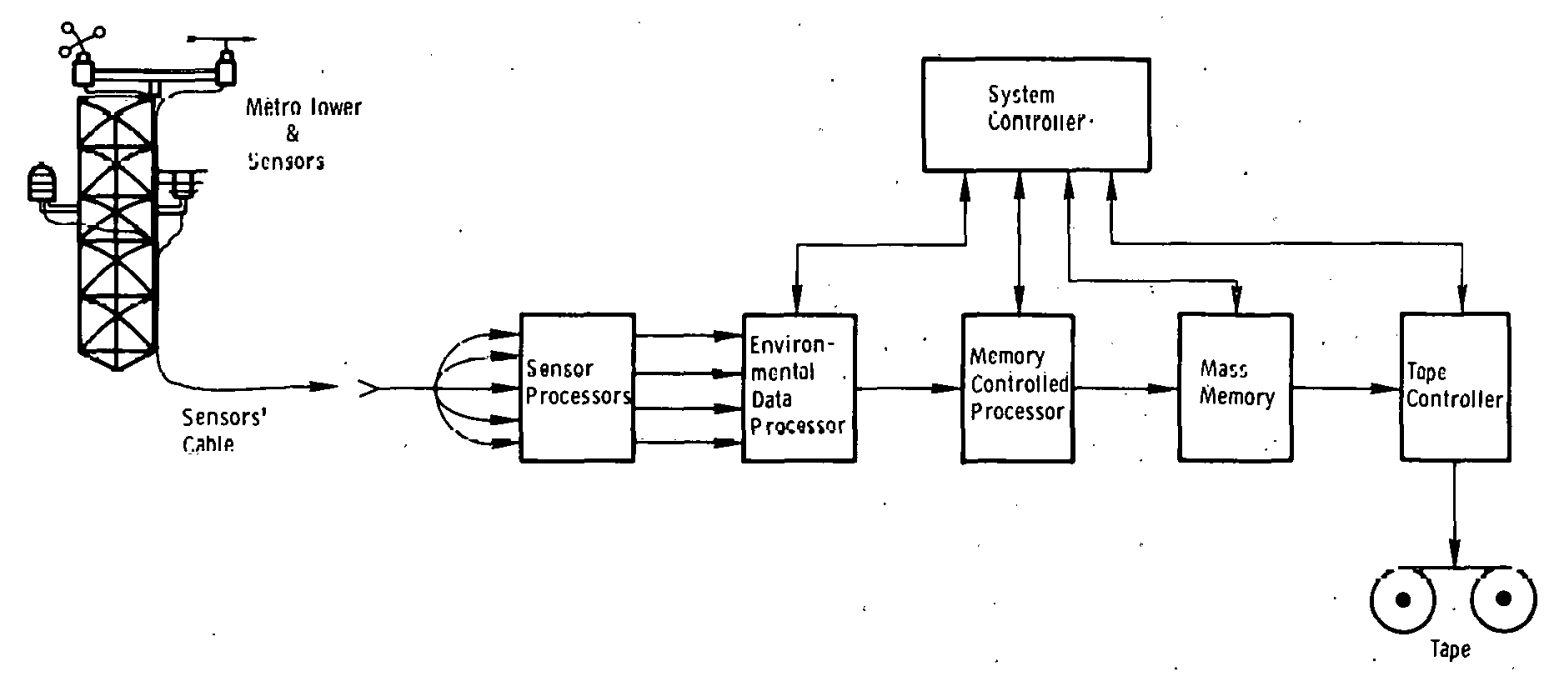

Figure 1. Overall Adaptive Intrusion Data System Diagram 
TABLE I

AIDS Metro Data Rocky Flats

\begin{tabular}{|c|c|c|c|}
\hline Channel & Data, Location & Units & Range \\
\hline 0 & Temperature, Trailer & ${ }^{\circ} \mathrm{F}$ & -30 to +130 \\
\hline 1 & Wind Speed, Trailer & Miles per hour & 0 to 100 \\
\hline 2 & Wind Direction, Trailer & Degrees azimuth & 0 to 360 \\
\hline 3 & Relative Humidity, Trailer & $\%$ & 0 to 100 \\
\hline 4 & Precipitation Rate, Trailer & Inches per hour & 0 to 9.99 \\
\hline 5 & Potential Gradient, Trailer & (Volt/meter $) \div 10$ & -999 to +999 \\
\hline 6 & Precipitation Accumulator, Trailer & Hundredths of an inch & 0 to 255 \\
\hline 7 & $\begin{array}{l}\text { Wind Speed, Remote, Corner } \\
\text { Sectors } 4 \& 5\end{array}$ & Miles per hour & 0 to 100 \\
\hline 8 & $\begin{array}{l}\text { Wind Direction, Remote, Corner } \\
\text { Sectors } 4 \text { \& } 5\end{array}$ & Degrees azimuth & 0 to 360 \\
\hline 9 & $\begin{array}{l}\text { Wind Speed, Remote, South End, } \\
\text { Sector } 3\end{array}$ & Miles per hour & 0 to 100 \\
\hline 10 & $\begin{array}{l}\text { Wind Direction, Remote, South End, } \\
\text { Sector } 3\end{array}$ & Degrees azimuth & 0 to 360 \\
\hline
\end{tabular}

All data are right justified, straight binary coded. Bit 11 is the sign bit for all channels. " 1 " indicates that data are positive $(+)$, and " 0 " indicates that data are negative $(-)$. For location purposes, Bit $0=\mathrm{LSB}$ is rightmost bit and Bit $11=$ MSB is leftmost bit.

\section{Environmental Data Processor Description}

Figure 2 is a detailed block diagram of the EDP. The outputs of the commercially supplied sensor processors are fed differentially to the EDP; i.e., both signal high $(+)$ and signal low (-) are transmitted via a twisted-pair cable. The front end of the EDP consists of IC instrumentation amplifiers which buffer and differentially amplify the sensor processor outputs. This scheme helps minimize common-mode signal errors resulting from spurious interference on the signal lines.

As evident from Figure 2, the analog inputs from the metro processors are routed through a multipole relay into instrumentation amplifiers. The analog output of a calibration circuit is also fed to contacts on this relay, and the amplifier inputs can be switched between data and calibration upon command from the System Controller (a Nova 2 minicomputer). Ordinarily, of course, the amplifier inputs are connected to a data source, but periodically a calibration sequence is run. The information obtained in a calibration run can provide valuable assistance in interpreting recorded data should the system malfunction noncatastrophically. For instance, if an amplifier drifts or its gain deviates, or if any system nonlinearities become pronounced, examination of the known calibration values can provide a basis for adjustment of the recorded data to yield acceptable accuracy, at least until the malfunction can be isolated and corrected in the field. 


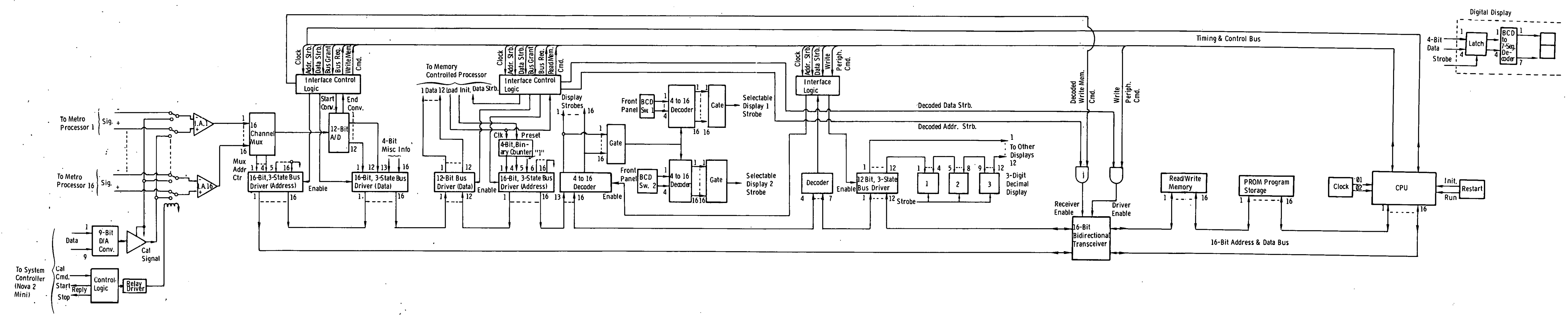


The outputs of the instrumentation amplifiers feed into a 16-channel multiplexer where they are concentrated by time-division-multiplex onto:a single line. This line in turn feeds a 12-bit, analog-to-digital converter. The 12-bit output of the converter is tied to a tristate buffer, where it is combined with four bits of miscellaneous information (sign bit, digital filter control, timed pulse, etc.). The end-of-conversion signal from the A/D converter initiates a bus request to the IMP-16 CPU, which responds with a bus grant signal when the 16-bit address/ data bus becomes free and no higher-priority bus requests are active (the IMP utilizes a fourlevel priority for bus control). When the bus grant is received, it triggers a sequence of commands and signals which accomplish the data transfer. First, a write memory command is generated and passed to the CPU, which informs the IMP that data will be written into its read/ write memory during the present bus cycle. Next, the interface control logic outputs an enable for the 16-bit, tristate address buffer. (See Figure 2; the IMP has a common 16-bit, tristate bus for both address and data, which are time-multiplexed (address first, then data) onto the bus. The tristate structure of the bus allows many peripherals to be connected directly to the bus through separate buffers.) The address buffer is fed by the four-bit address counter from the inultiplexer, which contains the location of the current channel (input) connected to the $A / D$ converter. This address is placed on the bus and, when combined with appropriate signals from the CPU, "opens" the memory location where the data will be stored (raw, unprocessed data from the 16 input channels are placed in memory locations 0 through 15). Immediately following the address strobe, a data buffer enable is generated which strobes the 16-bit data (12 A/D bits, 4 miscellaneous bits) onto the bus and consequently into the "opened" memory location. The entire transaction described occurs within $1.04 \mu \mathrm{s}$, the length of a bus cycle. The bus cycle extends from removal of the bus grant until termination of the write memory command. The basic $1.04-\mu s$ length can be extended if necessary to facilitate use of slow access memories. Understanding of the data transfer between $A / D$ and memory may be enhanced by referring to the fundamental timing diagram shown in Figure 3.

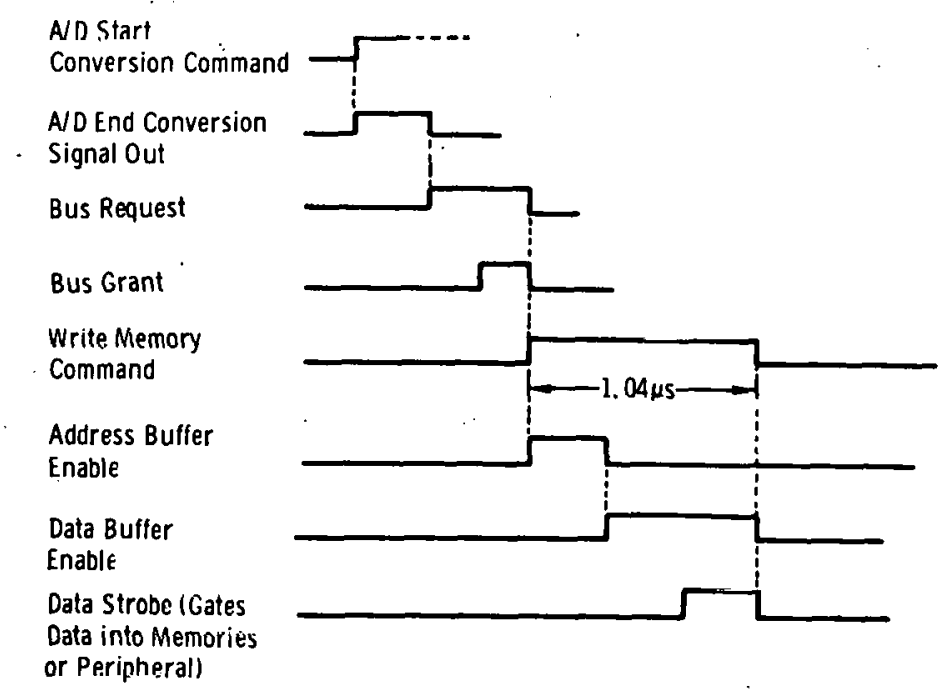

Figure 3. Interface Timing Diagram 
The technique of writing data directly into central memory via a Direct Memory Access (JMA) scheme, independent of software control, instead of interrupting the CPU and inserting the raw data directly into the respective software routine, was chosen because of the ease of implementation, speed, and flexibility which it afforded. The insertion of digitized, unprocessed inputs directly into memory allows them to be retrieved by the individual data routines during the normal sequence of execution without the need to incorporate interrupt service routines for each data input.

As each data parameter is processed by the IMP, it is again stored in memory as well as output to a display. The display panel consists of eight 3-digit LED displays. Six of the displays are dedicated, but the remaining two can accommodate any of the 16 possible data channels. The desired parameter for display is selected via a 16 -position thumbwheel switch mounted on the front panel. To minimize cabling between the front panel and the logic card backplane, the displays are multiplexed, with common data lines and a separate strobe line tied to each three-digit display.

The display hardware, as well as the logic contained inside the LED display digit, is shown in block form in Figure 2. Data output to the displays is accomplished by use of an output instruction in the IMP software. The processed data are sent directly to the displays from a register in the IMP CPU and are not transferred to the displays from memory (although the data are also stored in memory). The software I/O instruction automatically generates all necessary timing and control signals, which the selected peripheral (the group of displays) decodes and uses to strobe data into the proper display at the correct time.

Since most of the meteorological data vary sluwly, they are sent to the displays immediately after being processed by the respertive software routines. However, to minimize display flicker caused by rapidly changing wind speed and direction, the latter parameters are smoothed through a digital filter subroutine before being sent to the displays. The filter subroutine, as well as ail other software routines, is explained further in the appendix, which contains a complete listing of the Rocky Flats Environmental Data Processor control program.

'l'he processed environmental data must also be made available for permanent storage on indgnetle tape, slince automatic recording is essential for the large amounts of data handled by the system of which the EDP is a part. However, the EDP itself does not have a direct tape interface, but passes its data to a Memory Controlled Processor (MCP; see Figure 1). The MCP in turn combines the environmental data with all other collected data and formats the composite for tape storage. 
The EDP-MCP interface is shown in Figure 2. The processed environmental data to be transferred to the MCP are temporarily stored in read/write memory in the EDP. When the MCP initiates a data transfer, it first issues an initialization pulse to the EDP. This pulse presets a counter which is connected to the IMP address/data bus via a tristate bus driver. After setup, the MCP then issues a load pulse every $8 \mu \mathrm{s}$ until all data words are transferred. The load pulse steps the address counter and also triggers a bus request to the IMP. When a bus grant is received from the microprocessor, the address of the desired word is placed onto the IMP bus. When the address portion of the bus cycle is terminated (see Figure 3 ), the data appear on the bus. After the data have settled, the EDP generates a strobe pulse for the MCP to use to latch the word into its data buffer. The MCP keeps track of the number of active environmental channels and, when all data words have been transferred, it terminates the transaction by inhibiting further load pulses.

\section{Packaging}

Figure 4 shows the data display and logic chassis containing most of the Sandia-designed circuitry utilized in the EDP. Figure 5 shows the full 4-bay rack which houses all of the AIDS system.

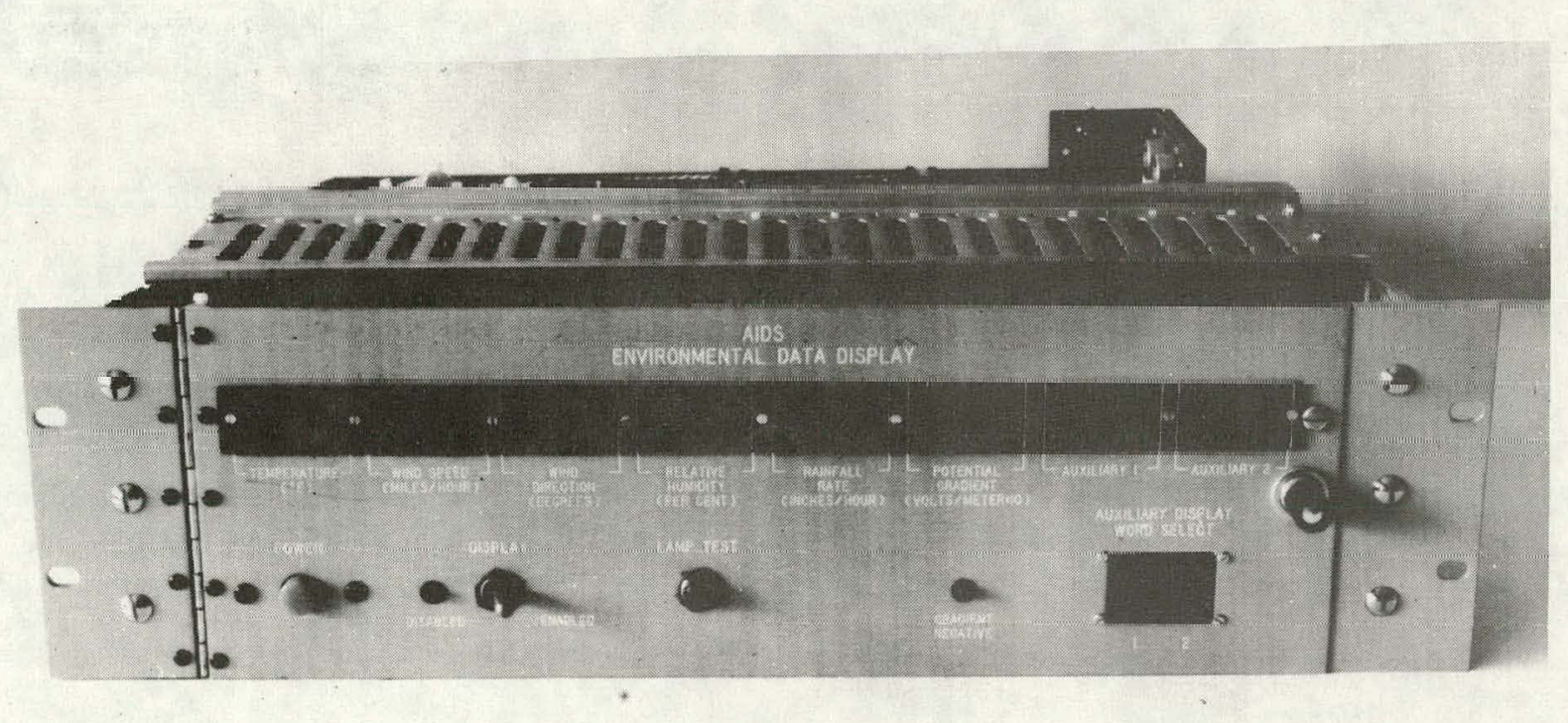

Figure 4. EDP Logic and Display Chassis 


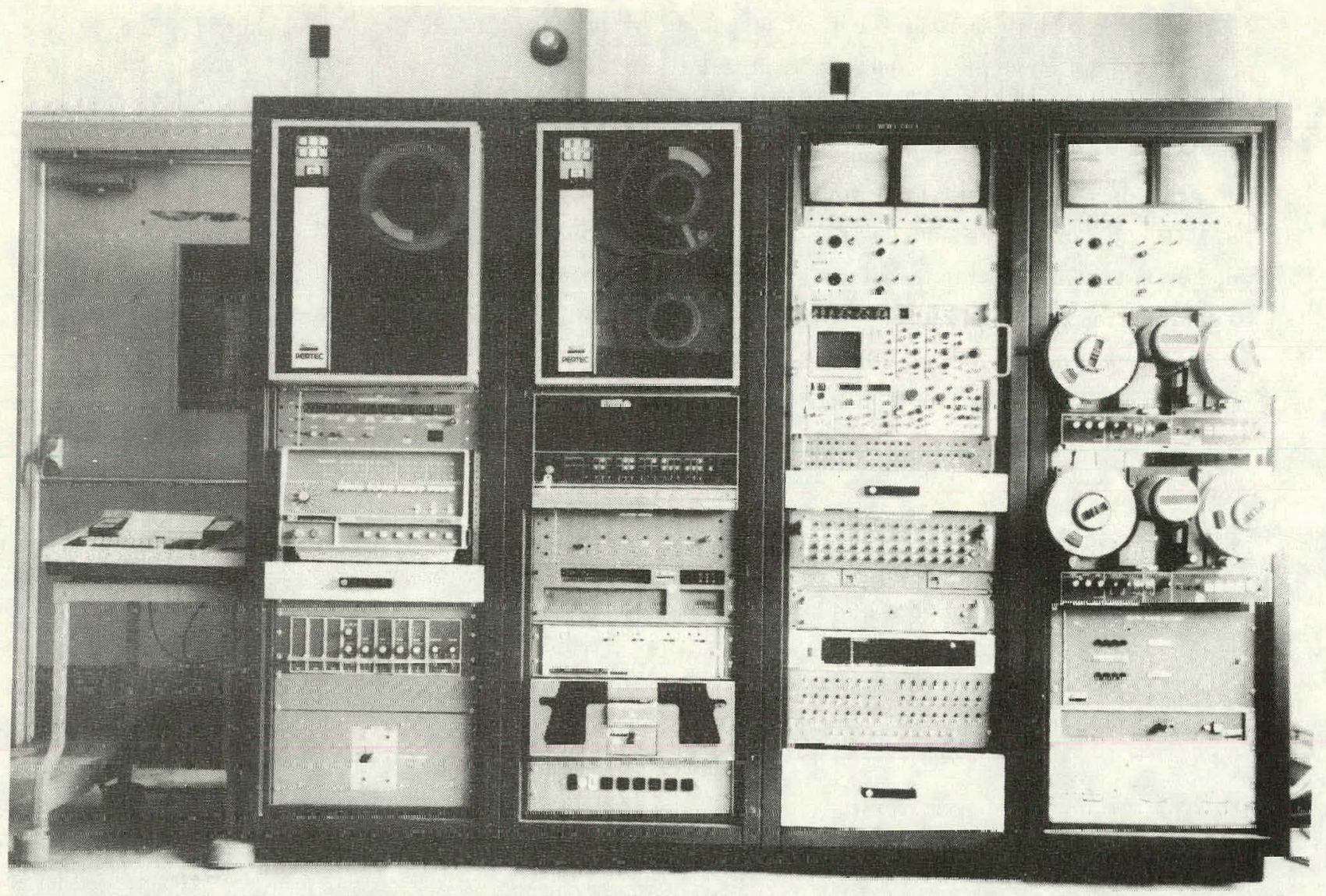

Figure 5. AIDS System Hardware 


\section{APPENDIX}

This appendix contains a complete listing (with comments) of the control software for the Environmental Data Processor (EDP) located at Rocky Flats, Colorado. Since it was initially anticipated that the microprocessor in the EDP might be used to perform other functions as the overall system was developed, more memory (both read-only memory, ROM, and read/write memory) than was necessary for the EDP was included to accommodate subsequent expansion of the system. A total of 8,000 active memory locations are avajlable for software and data storage in the Rocky Flats EDP, including $4 \mathrm{~K}$ of ROM for program storage and $4 \mathrm{~K}$ of read/write memory for scratchpad, temporary storage, and data storage. 
TYPE ADS2

$[15: 42: 32]$

ADAPTIUE INTRUSION LATA SYSTEM (AIDS) ENUIROMMEIVTAL LATA PROCESSOR SYSTEI PROGRAM TO RUN OIN INATIONAL SEMICOINDUCTOR IMP $16 \mathrm{~L}$ WICROPROCESSOR. THIS PROGRAL PROUILES SOFTWARE COINTPUL FOR THE EINUIRUINMENTAL PROCESSOR LOCATED AT ROCKY FLATS, COLC.

PROGRAM IS STORED IN READ ONLY MELIORY (ROLi) ON A $4 K$ ROM MENORY BOAFD RESIDENT IN THE I6L CHASSIS. THE PROGRAM BEGINS AT RON MEIIORY LOCATION 61440 (FDOO HEX). THE 4096 RAM HEVIORY IS USED FOR CATA STORALE AIVL SCRATCHPAD.

INPUT DATA TO THE NICROPROCESSOR IS FRON A $12-B I T$ AINALLG TO UIGITAL CONVERTER. WHEIV THE FULL 12 BITS IS NOT NEELED FUR DATA REPRESENTATIOW, THE DATA IS TPUNCATEL IN THE PROCESSOR BY RIGHT SHIFTIING. INPUT SAMPLING RATE FOR THE A/E IS IO/SEC PER CHANNEL.

CHANNEL $\emptyset$ TEIIPERATURE ROUTINE FULLOWS. AS TENIP GOES FRON -30 TO + 130 DEGREES F, INPUT TO THE MICROPPOCESSOR GOES FROM - TO 160. SOFTWARE DETECTS. THE CROSSOVER AIND ADJUSTS THE DATA ACCORDINGLY.

- EXT D

$P:$

START:

LD 0,

SHR $\quad$ a. 4

ST $\quad 0.64$

LI $\quad 0.30$

SKG 0,64

INP POS

SUB $\quad 0,64$

JMP OUT

POS: LD $\quad 0.64$

SUB 0.030

SETEIT 11

;

OUT: ST 0.16

CLREIT 11

JSR . OBNECE

LI $\quad 1,0$

1.. D 2.64

SKG 2,D30

$A L D \quad \forall, H D U D$

JSR OOUTPT
; SUPPRESS ERPOR HESSAGES I IN ASSEHBLY RESULTING FROM USE OF EXTENLED INSTRUCTION SET .

;BIAS ASSEMBLER TO IST MEMORY LOCATION. ;FETCH TEMP DATA.

; TRULICNTE TO 8 BITS.

- SET $A C Q=30$.

ISKIP IUEXT INST IF TEMPKD.

; SUETRACT 3Q-DATA.

; SUBTRACT DATA-30.

:BIT II OF ACE = I INDICATES DATA

IS POSITIVE.

; STORE ADUUSTED EATA.

;GO TO EINARY TO BCD CONUERSION ROUTINE. ; SET ACI TO ALDRESS TEMP EISPLAY.

; SKIP INEXT INST IF TEMP>O.

; SET MINUS IN DIGIT 3 .

CHANNEL 1,7, AND 9 WIND SPEEL AND CHANNEL 2,8, AND 10 WIND EIRECTION ROUTINES FOLLOW. DATA IN THESE CHANNELS IS DIGITALLY FILTERED BEFORE OUTPUTING TO THE DISPLAYS. THE DIGITAL FILTER CALL IS INITIATED BY A CONTROL BIT (BIT I4) IN THE WINL SPEED CHANNEL 1 INPUT. THIS CONTROL BIT IS IN TURN DERIVEL FROIN A 1-PULSE/SEC SIGNAL FROM THE TIME CODE TRANSLATER. THE CONTROL BIT IN EFFECT DETERIINES THE SAMPLE RATE OF THE FILTER AND SETS THIS RATE AT 1-SAMPLE/SEC US IO/SEC FOR THE CHANNEL INPUTS. DATA STORED IN MEMOPY FOR WRITING ON MAGNETIC TAPE IS NOT FILTERED. 


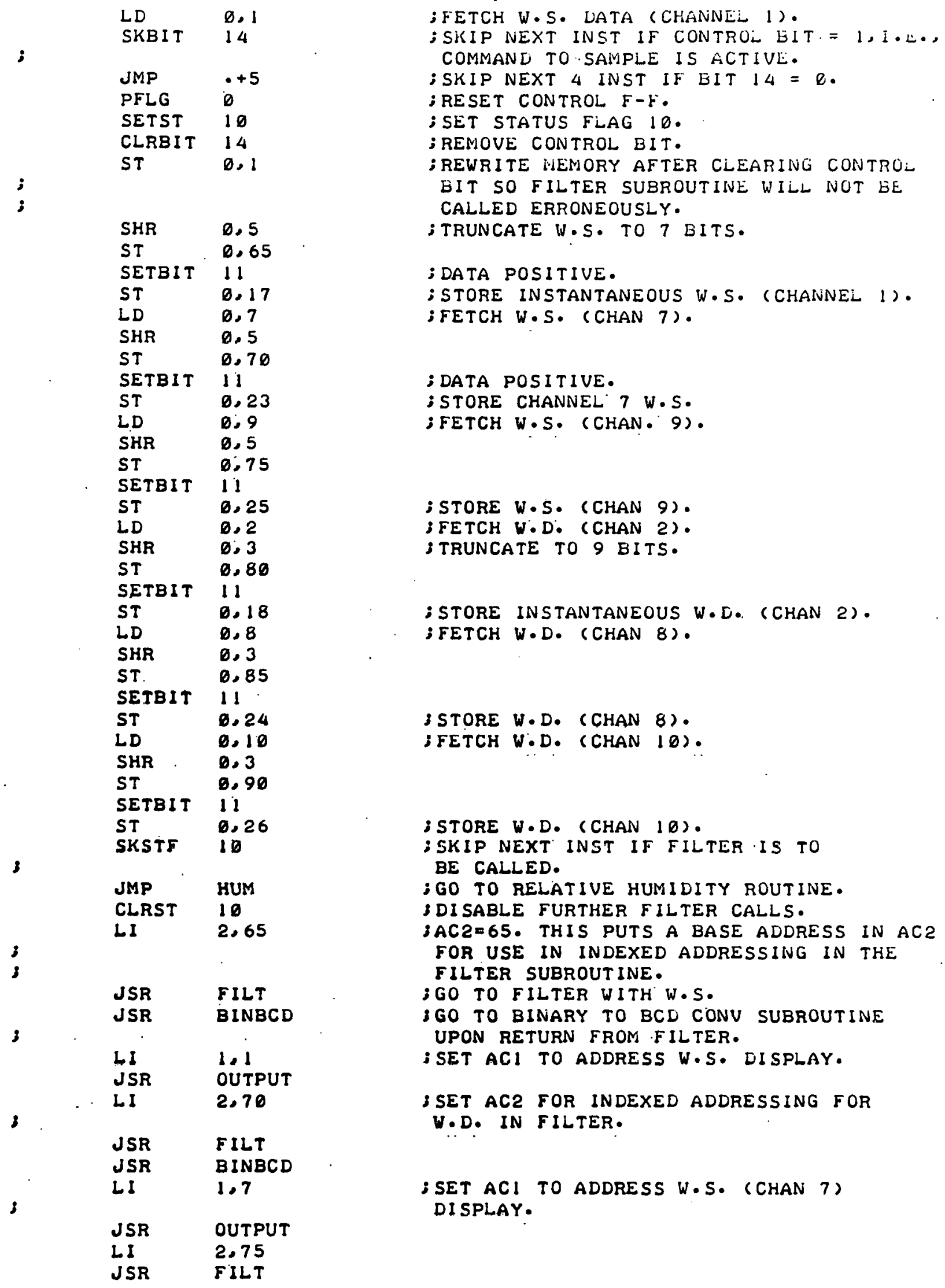




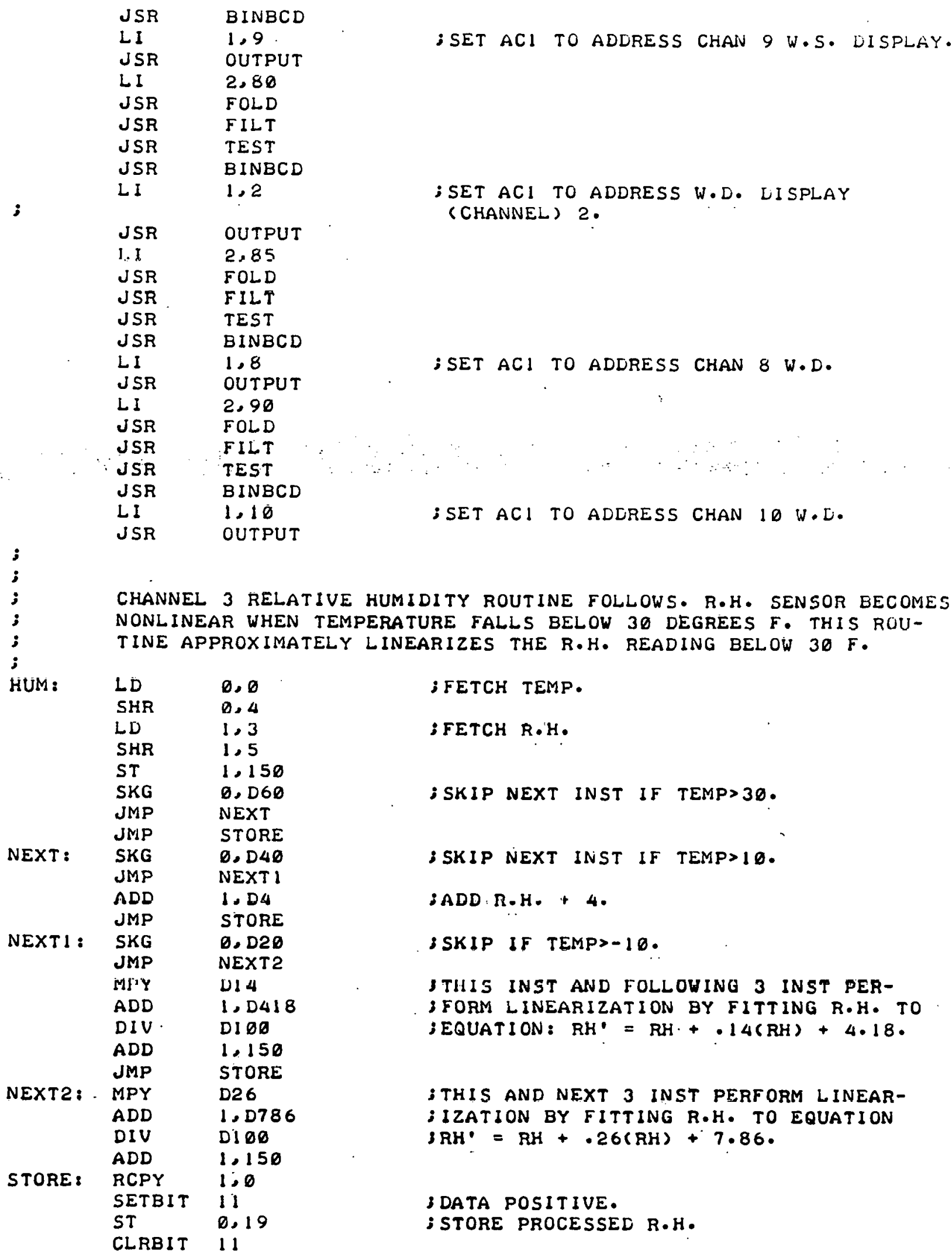




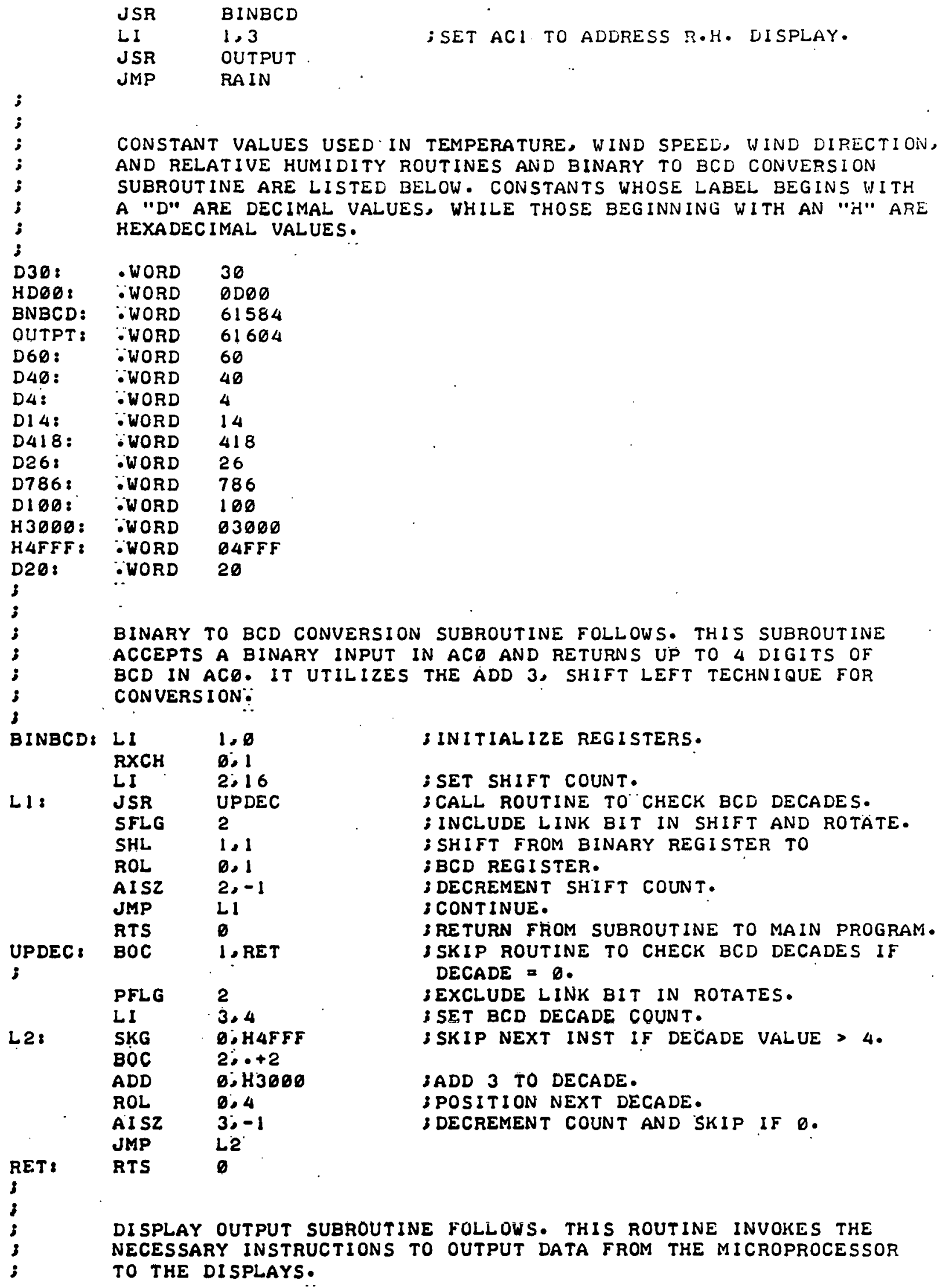




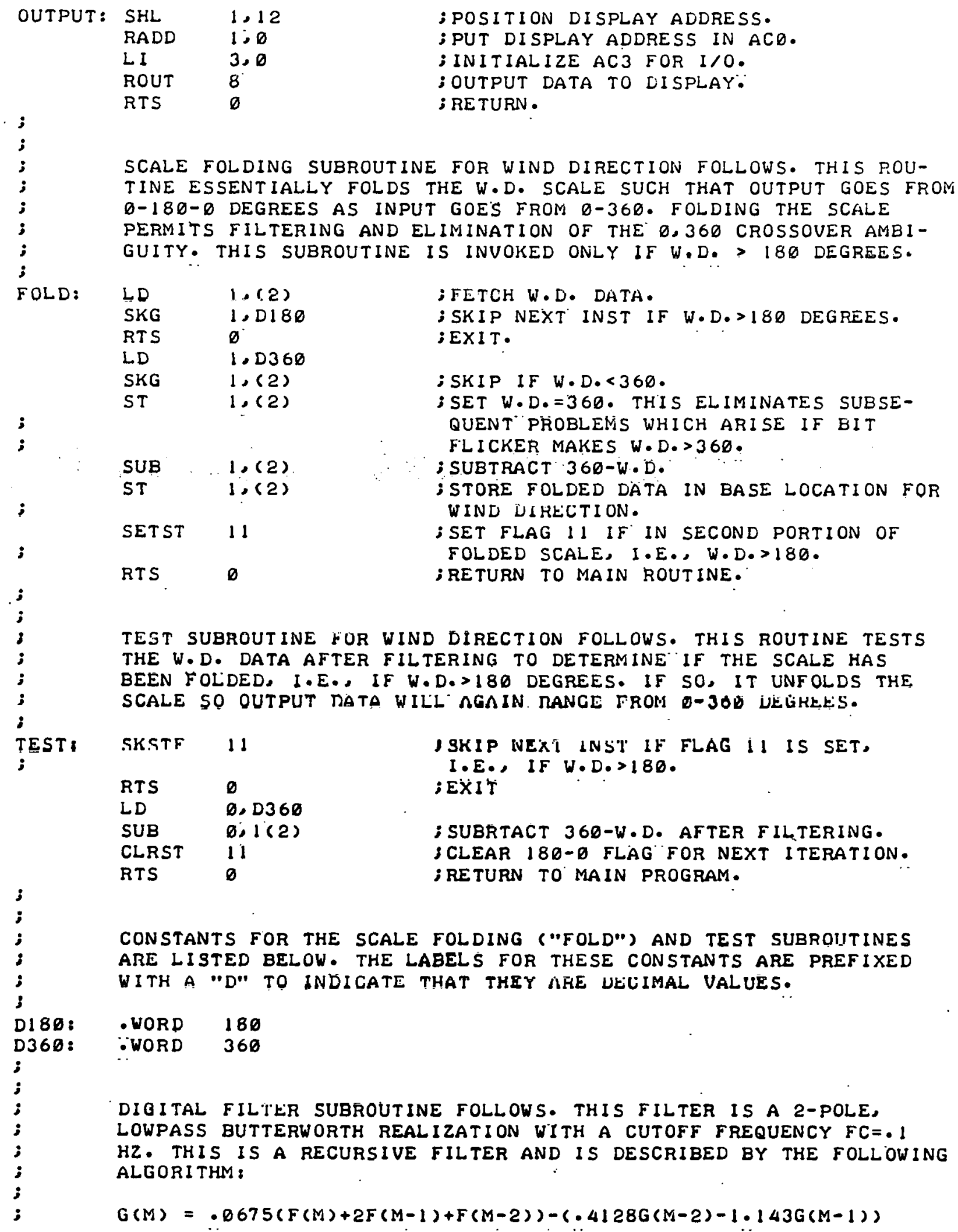

SCALE FOLDING SUBROUTINE FOR WIND DIRECTION FOLLOWS. THIS P.OUTINE ESSENT IALLY FOLDS THE W.D. SCALE SUCH THAT OUTPUT GOES FROM

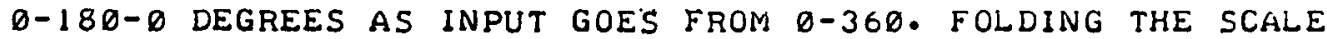
PERMITS FILTERING AND ELIMINATION OF THE 0,360 CROSSOUER AMBIGUITY. THIS SUBROUTINE IS INUOKED ONLY IF W.D. > 180 DEGREES.

; POSITION DISPLAY ADDRESS. ; PUT DISPLAY ADDRESS IN ACD. IINITIALIZE AC3 FOR I $/ 0$. ;OUTPUT DATA TO DISPLAY: ; RETURN.

$\begin{array}{ll}\text { LD } & 1,(2) \\ \text { SKG } & 1, D 180 \\ \text { RTS } & 0 \\ \text { LD } & 1.0360 \\ \text { SKG } & 1,(2) \\ \text { ST } & 1,(2) \\ & \\ \text { SUB } & 1,(2) \\ \text { ST } & 1,(2) \\ \text { SETST } & 11 \\ \text { RTS } & 0\end{array}$

TEST SUBROUTINE FUR WIND DIRECTION FOLLOWS. THIS ROUTINE TESTS THE W.D. DATA AFTER FILTERING TO DETERMINE IF THE SCALE HAS BEEN FOLDED, I.E., IF W.D.>180 DEGREES. IF SO, IT UNFOLDS THE SCALE SQ OUTPUT NATA WILL nGAIN. RANGE FROM D-3OB UELKLES.

$\begin{array}{ll}\text { SKSTF } & 11 \\ \text { RTS } & 0 \\ \text { LD } & 0,0360 \\ \text { SUB } & 0: 1(2) \\ \text { CLRST } & 11 \\ \text { RTS } & 0\end{array}$

CONSTANTS FOR THE SCALE FOLDING ("FOLD") AND TEST SUBROUTINES ARE LISTED BELOW. THE LABELS FOR THESE CONSTANTS ARE PREFIXED WITH A "D" TO INDICATE THAT THEY IRE UELIMAL VALUES.

$\begin{array}{ll}\because \text { WORD } & 180 \\ \because \text { WORD } & 360\end{array}$

DIGITAL FILITER SUBR̄OUTINE FOLLOWS. THIS FILTER IS A 2-POLE, LOWPASS BUTTERWORTH REALIZATION WITH A CUTOFF FREQUENCY FC .1 HZ. THIS IS A RECURSIVE FILTER AND IS DESCRIBED BY THE FOLLOWING ALGORITHM:

$G(M)=.8675(F(M)+2 F(M-1)+F(M-2))-(.4128 G(M-2)-1.143 G(M-1))$ 


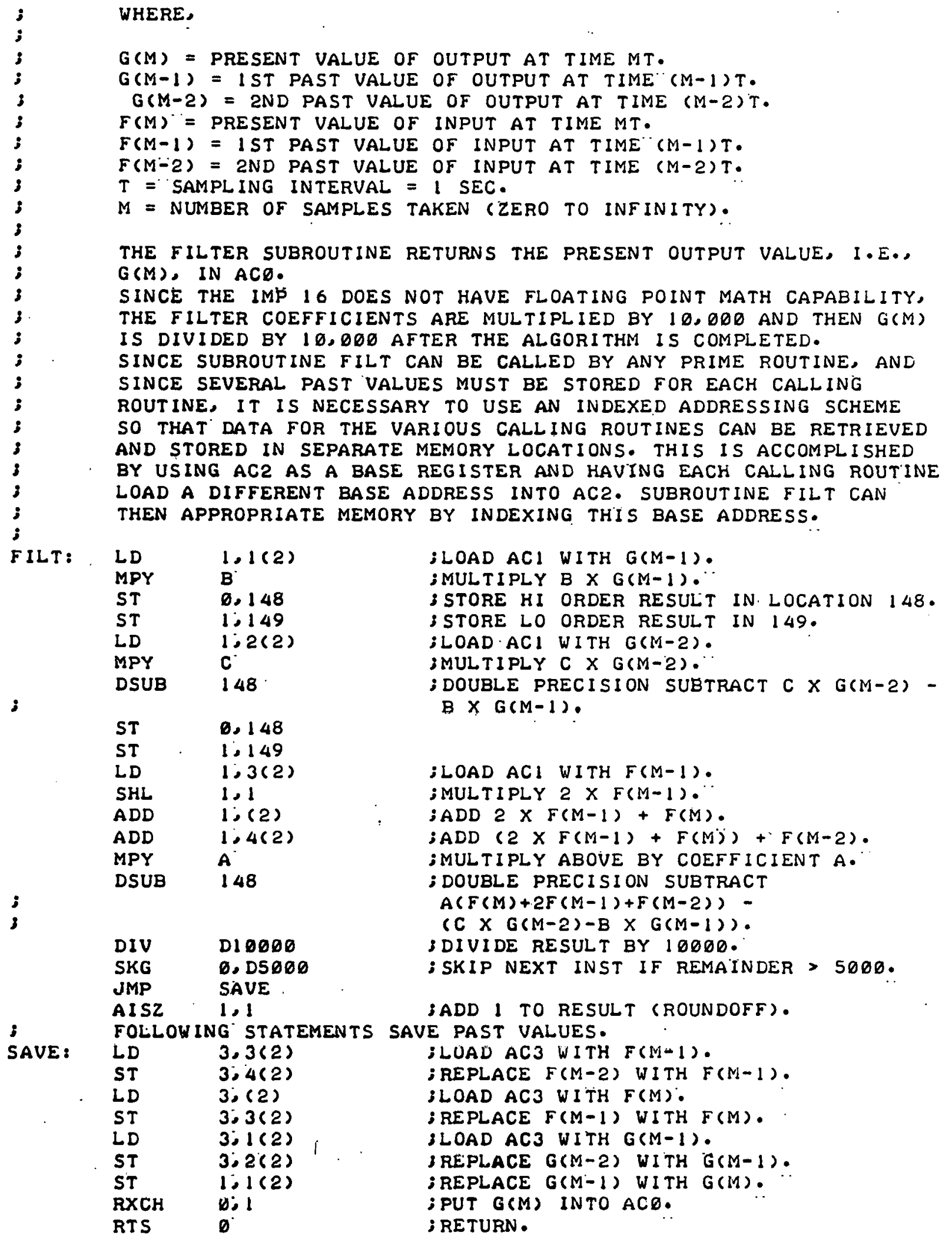


CONSTANT VALUES FOR THE FILTER ("FILT") SUEROUTIIVE ARE LISTEL BELOW. THE LABELS FOR THESE CONSTANTS BEGIN UITH A "L" TO INDICATE THAT THEY ARE DECIMAL VALUES. THE CONSTANTS "A", "B" AND "C" ARE THE FILTER COEFFICIENTS.

$\begin{array}{lll}\text { D10000: } & \text { WORD } & 10000 \\ \text { D5000: } & \because \text { WORD } & 5000 \\ \text { A: } & \because \text { WORD } & 675 \\ \text { B: } & \because \text { WORD } & 11430 \\ \text { C: } & \because \text { WORD } & 4128\end{array}$

CHANNEL 4 RAINFALL RATE ROUTINE FOLLOWS. RAIN ACCUIVULATUR READING IS TAKEN ONCE EVERY 4-MINUTES. SINCE. OI INCH OF PRECIPITATION IS MINIMUM SENSITIVITY OF ACUMULATOR, THE MINIMUM DETECTABLE RAIN RATE IN INCHES/HOUR IS $(60 / 4) \times \cdot 81=.15$ IN/HR. SAMPL ING OF ACCUMULATOR IS CONTROLLED BY A BIT (BIT 14 ) WHICH IS DERIVED FROM A 1 -PULSE/4-MIN. SIGNAL.

RAIN :
LT

SHR

CLRBI SETBIT

ST

CLRBIT

JSR

l. I

JSR

LD

SKBIT

JMP

PFLG

CLRBI T

ST

SHR

RCPY

SUB

RCPY

$\mathrm{BOC}$

ST

LD

$A D D$

MPY

RCPY

SETBIT

ST

CLRBIT

$S T$

J SR

LI

J SR
0,4

$0: 160$

$0 ; 4$

10

11

0.22

11 BINBCD

1,6

OUTPUT

0.160

14

GRAD

3

14

0,4

$0 ; 4$

0,2

$0 ; 161$

0,1

$23+4$

$0 ;\lceil 61$

1: DES6

$1 ; 161$

DI5

1,0

11

0.26

11

2. 161

BINBCD

1,4

OUTPUT
;FETCH RAIN ACCUMULATOR OUTPUT.

: TRUNCATE TO 8 BITS.

; REMOVE CONTROL BIT.

; DATA POSITIVE.

; STORE INSTANTANEOUS ACCUMULATOR OUTPUT.

- SEI ALI TU ADDRESS ACCUM DISPLAY.

S SKIP IF CONTROL BIT IS HIGH.

; GO TU POTENTIAL GRADIENT ROUTINE.

S RESET CONTROL F-F.

; CLEAR CONTROL bIT FROM aCo.

; REWRITE MEM AFTER CONTROL BIT REMOVED.

- SUBTRACT PREUIOUS ACCUM READING FROM PRESENT READING.

S SKIP NEXT 3 INST IF ACO>B.

; IF $A C \theta<\theta$, NEXT 3 INST WILL CHANGE

3 CONTENTS TO AN EQUIVALENT POSITIVE S VALUE.

;MULTIPLY ACCUM DIFFERENCE BY $(60 / 4)=15$ TO ADUUST TO HOURLY RATE.

- DATA POSITIVE.

S STORE HOURLY RATE.

; STORE PRESENT ACCUM READING.

3 SET ACI TO ADDRESS RAIN DISPLAY. 


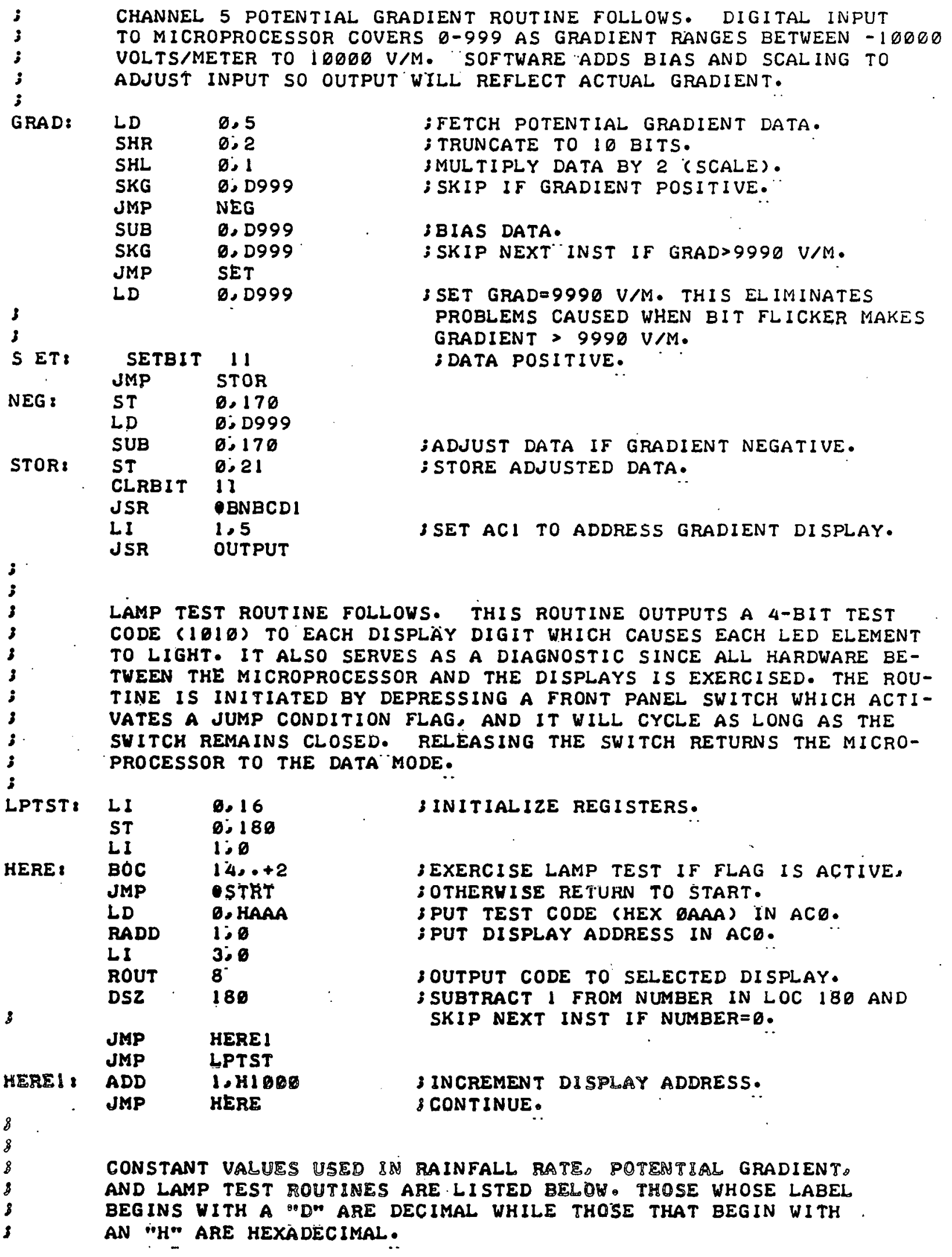




$\begin{array}{lll}\text { D15: } & \text {.WORD } & 15 \\ \text { D256: } & \because \text { WORD } & 256 \\ \text { D999: } & \because \text { WORD } & 999 \\ \text { BNBCD1: } & \text { WORD } & 61584 \\ \text { STRT: } & \because \text { WORD } & 61440 \\ \text { H1000: } & \because \text { WORD } & 01000 \\ \text { HAAA: } & \because \text { WORD } & \text { OAAA } \\ & \because \text { END } & \end{array}$


DISTRIBUTION:

1739 J. D. Williams (2)

9420 T. L. Pace

9421 M. J. Navratil

9421 M. S. Rogers (10)

8266 E. A. Aas

3141 C. A. Pepmueller (Actg) (5)

3151 W. L. Garner (3)

ERDA/TIC (25)

For ERDA/TIC (Unlimited Release)

(R. P. Campbell, 3172-3) 